\title{
Ellen M. Rogers as a Feminist and Orientalist Travel Writer: A Study of her A Winter in Algeria: 1863-4 (1865)
}

\author{
Mouloud Siber \\ University of Tizi-Ouzou, Algeria \\ siberm@yahoo.fr
}

\begin{abstract}
This article studies the Orientalist and Feminist discourses that underlay Ellen M. Rogers's A Winter in Algeria: 1863-4 (1865). Her conception of Algeria reproduces the Victorian imperialist attitude toward the Algerian as inferior to the European in order to celebrate British imperial power. Underneath this colonial discourse, the writer proclaims her feminist point of view about empire and juxtaposes feminist attitudes in Victorian Britain with the degraded condition of the Oriental woman. To contribute to Victorian feminist struggle for gender equality, she identifies with the suffering of Muslim Algerian women under male domination and compares their confinement to the harem and their veiling to Victorian "separate spheres" ideology. From this perspective, Rogers presents the profiles of the Orientalist as defined by Edward Said (1978) and the feminist as defined by Antoinette Burton (1994). Said limits his discussion of Orientalism to male writers and travelers who construct imperialist views about the colonial world and its people. However, Burton argues that many Victorian travel writers were women who not only circulated Orientalist ideas but also constructed a feminist discourse. Women writers found in the colonial world ways to cross the boundaries of gender and power in order to criticize male writers who insisted on women's inferior status. In sum, the major claim made in this article is that Ellen M. Rogers projects a feministOrientalist view in her travel account about French Algeria.
\end{abstract}

Keywords: Feminism, Orientalism, Victorian travel writing, Algeria, Rogers, Oriental woman, Victorian woman 


\section{Introduction}

In postcolonial studies, questions concerning gender polemics and the power of empire often go hand in hand. The intersection of these two realms is substantial in Victorian literature which generated controversy about women authors' place in the literature of empire. In Orientalism, Edward Said argues that the burgeoning interest in empire during Queen Victoria's reign created a type of literature that founded an imperial, Orientalist tradition. His discussion of Orientalism focuses more on men's writings than women's. Thus, in Burdens of History: British Feminists, Indian Women, and Imperial Culture, Antoinette Burton concentrates on women's travel writing and periodicals which she considers to be contributing to the construction of the Orientalist tradition. She asserts that Victorian women profited from the imperial enterprise by confirming in their writings the Orientalist tradition which, in turn, they used to express their feminist struggle against their male-defined inferior status at home (Burton, 1994: 5). This resulted in a new, ground-breaking genre, namely Feminist Orientalism advanced, for instance, in women's travel writing. ${ }^{1}$ Even if many such writers were concerned with British colonies like India, other women like Ellen M. Rogers, Matilda Betham Edwards and Lloyd Evans looked to non-British colonies which constituted the same repository for their feminist and Orientalist ideas as the British ones did.

In A Winter in Algeria: 1863-4 (1865), Ellen M. Rogers accounts for her travels in French Algeria. ${ }^{2}$ Frustratingly, little is known about her. She was the wife of Rev. George Albert Rogers, with whom she co-authored The Folded Lamb: or, Memorials of an Infant Son (1852). She also wrote The Coronation Stone and England's Interest in It (1880). However, A Winter in Algeria: 1863-4 seems to be the text which most promotes Orientalist ideas since it narrates her tours in colonial Algeria during a period known for Orientalism. She and her husband traveled to Algeria and visited Algiers and its vicinity from October 1863 to May 1864. They spent the first six months in Algiers; then they visited the neighboring towns of Blida, Medéa and Melliana after which they returned to Algiers for their departure to England. Her husband was in Algiers for an Evangelical mission; she had missionary motivations and the desire to visit exotic Algeria. Once in Algiers, she grew more interested in the condition of Algerian women.

Scholarly attention to Rogers's travel account or to those of other women travelers to Algeria is sparse. The existing scholarship tends to overemphasize writings about Victorian travelers in India and other British colonies and to overlook those writings about Algeria, which became a destination for Victorian women travelers. For instance, Sara Mills in Discourses of Difference: an Analysis of Women's Travel Writings and Colonialism (1991) makes no reference to Victorian travel writings about Algeria although there were many women who crossed the boundaries of the British Empire to voice their feminist and imperialist/ Orientalist interests in Algeria. Rogers, Edwards, and Evans were among the forerunners of Victorian women travelers. Deborah Cherry in "Earth into World, Land into Landscape: the Worldling of Algeria in NineteenthCentury British Feminism" (2002) argues that Victorian women travelers viewed Algeria as an exotic site for feminist engagement; the sale of their "cultural forms" 
helped them to fund the feminist activities in Britain. However, Cherry overlooks the discursive aspects of their writings, especially the intersection of the feminist stance with the Orientalist one. These two works do not analyze Rogers's text which frustratingly lacks scholarly attention. To fill this gap, Sadia Seddiki's "Mrs. Ellen G. Rogers's A Winter in Algeria and the Perpetuation of Colonial Discourse"4 (2010) studies Rogers's work as an example of colonialist discourse on the French domination of Algeria. Seddiki's main argument is that Rogers reproduces the cultural and social stereotypes set up by the French to describe Algerians in order to justify their imperial domination. However, there is room for further debate on the significance of the text's allusions to Britain's imperial power and the intersection of gender and empire in it.

This article focuses on studying the Feminist and Orientalist discourses that underlay Rogers's travelogue A Winter in Algeria: 1863-4 (1865). In her text, she retools the Victorian imperialist representation of Algeria as inferior to European powers, especially Britain, to participate in imperial culture. This allows her to relocate Victorian feminist ideologies ${ }^{5}$ and the struggle for gender equality to the male-centered Algerian context. She does so by identifying with the suffering of Muslim women under male domination in order to promote her feminist commitment to more socio-cultural rights for Victorian women and their enfranchisement. Using popular Orientalist views of the time about the colonized "Other," she argues for female agency in Britain's imperial culture. People, it is said, live by metaphors, and one of these metaphors for Victorian women travelers is the degraded condition of Muslim women standing for that of Victorian women and the need for emancipating all women.

Thus, Rogers wears the mantles of an Orientalist as defined by Said (1978) and a feminist as defined by Burton (1994). Because Said relatively restricts Orientalism to male authors who represent the Orient the better to dominate it, Burton argues that many Victorian women travelers integrated Orientalist discourse so as to circulate a feminist one. The colonial world provided women writers with sites in which they could cross the boundaries of gender and power to criticize male writers who confirmed the status of "angels in the house" (Mills, 1991: 27) attributed to women. The "separate spheres" ideology of the time confined women to the domestic space and made them protectors of the household. The ideology of the "fair sex" also dismissed women as "weak," "emotional," "irrational," etc. Thus, women had to deflate these ideologies by appropriate devices like traveling to distant territories and writing about them. In writing about her experiences in a French colony rather than a British one, Rogers differs from other imperial feminists, but she makes references to the condition of Victorian women and to British imperial interests there.

In terms of theoretical framework, I take as a starting point ideas borrowed from Said's Orientalism, particularly the manner in which the Orientalist author represents Orientals as Europe's inferior "Others." His concept of Orientalist "vision" involves "the rigidly binomial opposition" of the West and the Orient, "with the former always encroaching upon the latter" (Said, 1995: 227). It attributes to Orientals a static (Said, 1995: 239) and backward condition, thus contrasting them to advanced and superior Europeans. This Orientalist view is created by the West, for the West, and it is "no more 
than a will to power, a will to truth and interpretation and not an objective condition of history" (Said, 1995: 240). The implication is that the Orientalist interprets the Orient and Orientals and delivers them to the Western reader in a way that results from the desire to dominate it and departs from objective reality.

Because the Orient is the West's creation, other scholars appropriate almost the same concepts as Said in their definitions of colonized populations and their relation to the colonizer. For instance, in The Location of Culture (2004) Homi Bhabha bases his concept of "fixity" on Said's notion of Western vision and develops it through an analysis of corresponding stereotypes. Bhabha explains that these stereotypes are rooted in "a form of knowledge and identification that vacillates between what is always 'in place', 'already known' and something that must be anxiously repeated" (Bhabha, 2004: 94-95). Stereotypical discourse exaggerates on given representations of a category of persons as "object[s] of discrimination" (Bhabha, 2004: 114) in order to "fix" these representations as true. The stereotypes are negative, and their objective is to "construe the colonized as a population of degenerate types" (Bhabha, 2004: 101). Consequently, they are considered submissive to the moral bearing of the colonizer.

Rogers re-works the Orientalist representation of Algeria, but she overturns it to express her feminist ideas. Therefore, the ideas of Antoinette Burton will be the framework through which the author's feminist appropriation of Orientalism will be examined. Indeed, she calls "imperial feminism" (Burton, 1994: 1) the discourse propounded by British women travelers who allied their feminist cause with the interests of empire. Burton claims that in their travel writings Victorian women engaged with "relocating British feminist ideologies in their imperial contexts" (Burton, 1994: 2). They "enlisted empire and its values so passionately and so articulately in their arguments for female emancipation" (Burton, 1994: 5) and reproduced the "languages of imperialism" (Burton, 1994: 2). The "white woman's burden" of emancipating the Oriental woman consolidates their status as "imperial citizens" (Burton, 1994: 7). It allows them to "negotiat[e]" (Jenkins, 2004: 15) their place in the imperial tradition as women and British citizens. In other words, they support empire, its ideologies and its missionary policies to plead the cause of Victorian women.

\section{Rogers's Orientalist Attitude}

A Winter in Algeria was published in 1865 under Rogers's married name, Mrs. G. Albert Rogers. However, this does not keep her within the confines of the ideology of the "angel in the house." Her excursions in Algeria, with or without her husband, serve her as a tool for deflating this ideology. Her voyage to Algeria allows her to gather the material to narrate her travel impressions on the French colony and express her feminist and Anglo-centric interest in it. As an educated woman, she has the cultural status that gives her the power to narrate about Algerians and allows her to join colonialist discourse and to affirm her "role in the national political culture" (Burton, 1994: 1). This is her first step toward crossing the boundaries set up by men in Victorian society. 
Throughout her narrative, she voices the spate of Orientalist views about Algeria in Victorian Britain, and her text is steeped in references to British imperial identity as superior to the colonized Algerian to show that her discourse is part and parcel of the British Orientalist tradition.

Rogers's travelogue can be considered an Orientalist text on several counts. As soon as she arrives in Algiers, she starts viewing its people as politically, culturally, intellectually inferior to the French and other Europeans, especially the English. Due to their pretended inferiority, the 'natives' are dismissed as a subordinate race, ruled over by the supposed superior French "masters" (1865: 18). Politically, she claims that because the regime under which the Algerians were living was "despotic," they needed to be colonized. She illustrates this political inferiority by the state of Algiers where the rulers "had too often waded to the throne through blood," violence and danger (1865: 32). According to her prose, the Algerians used to live in states of anarchy because of their corrupt political regime(s). This is a rephrasing of Victorian views of Oriental countries like Algeria which are often associated with despotism. This view was cultivated by Victorian intellectuals and politicians. For example, John Stuart Mill claims that colonizers of "a superior people or a more advanced state of society" are entitled to interfere in the task of ruling less advanced people (1867: 97). He argues that Oriental despotism needs to be replaced by "enlightened" and "vigorous despotism [which] is in itself the best mode of government for training the people in what is specifically wanting to render them capable of higher civilization" (1867: 345-46). Furthermore, Said (Said, 1995: 32) quotes Arthur James Balfour's assertion that "Oriental despotism" is a historical fact of the East. This stimulated Europeans to claim for themselves the duty to help Orientals to get rid of their despots and put in place Western-like regimes.

Living in a state of anarchy due to despotism and tyranny is a contributing factor to the static condition of the colonized. Rogers asserts that even the Algerian people contribute to their country's "backwardness." For instance, she insists that they are often "lazy" (1865: 37). Thus, they do not endeavor to improve their condition and thus foster in advancement. They remain backward while the English are progressive. Therefore, they are caught in perpetual states of subordination and should look to the English in order to find the 'fittest' race for their rule. The average Englishmen engaged in Algiers "take infinite pains in training the ouvriers under them," but the "Arabs are usually so lazy" that they have to be trained with an iron fist (53). To flesh out her stereotype of the lazy 'native,' she contrasts the ingenuity and energy of Europeans with the impotence of the 'natives' stating that all that is European "is life and animation, all but these poor torpid, purposeless, and degraded-looking natives" (40). To her, the laziness of the Arabs is such that they need to be taught "the value of systematic work" (188) by Europeans.

Laziness and impotence are not the only stereotypes she appropriates in order to conform to the imperial tradition. She also adheres to the Victorian view of colonized people as morally degraded. For instance, the Algerians are associated with lying: "It is 
impossible to trust a word these people say" (Rogers, 1865: 30). Because of the Arabs' disposition to lying, they are also suspicious. She writes:

It is not so, that if you are known to take an Arab into your confidence, and friendship, at once some other Arab will warn you to beware of trusting him? 'He is a liar-he will deceive you-he will rob you', and so on. (184)

Arguably, the author uses this stereotype of lying and suspicion as its consequence in order to affirm an imperative of English imperial power. To her, this would be achieved through the teachings of the Gospels: "By this shall all men know that ye are My disciples, if you have love to one another" (184). ${ }^{6}$ Said asserts that the stereotypes of lying and suspicion are British (and French) Orientalist constructs whose aim is to legitimate imperial domination on moral grounds (Said, 1995: 39). Additionally, the dialectical thinking of Orientalism juxtaposes the immorality of the 'natives' with the moral bearing of Europeans who invest themselves with the "burden" or duty of disciplining the Oriental. ${ }^{7}$ Clearly, Rogers dwells so much on the stereotype of the Arab as an "inveterate liar" and "fixes" it, to borrow Bhabha's word, as a moral defect that needs amendment by the power of English discipline and morality.

Rogers's stereotypes do not stop at her portrayal of the Arabs, but they extend to the Moors. She argues that miscegenation engendered the Moors, who are the descendants of all the races that alternately landed on the shores of Algeria. Thus, they represent the Algerian equivalent for Eurasians. Adopting Orientalist vision, she describes them as "mean, cringing, indolent, false, cowardly, boasting, and void of strength, either mental or physical" (Rogers, 1865: 45). The transposition of this representation of the Moors to Europe's half-castes in the Orient agrees with Benita Parry's statement that in "popular fiction Eurasians were shown as debased and without dignity, as shrill and cringing, a warning against the mixing of the races" (Parry, 1972: 32). Like Eurasians who are compared to colonized Asians in British colonial discourse, the Moors join the Orientalist stereotyping of the Algerian as backward. Rogers's text portrays the Algerian Arabs and Moors as decadent to legitimate their need to be disciplined by English power that is present in Algeria through the economic and missionary enterprises.

To Rogers, the Algerians beseech the intervention of Europeans for their cultural and intellectual salvation. She states: "the poor Arabs begin to excite our interest greatly ... Would that these poor Arabs knew the value of the Lamp of Life!" (29; italics added) Given their backward condition, they need to be integrated into the enlightened work of the English, who contribute to implementing Victorian progress ${ }^{8}$ in Algeria. She celebrates the comforts that are taken by the English to Algeria. She writes: "the railroad, by the way, is entirely the work of English talent, aided by English capital" (38). The author reflectively dwells on the thought that "with English comforts, Algiers, or its vicinity, would be a charming residence for some ten months out of the twelve" (67). It was in Victorian Britain that the idea of England's mission to take the blessings of progress to non-European countries blossomed, and Algeria was one such 
country where "real work" was achieved by the English despite its status as a French colony.

Rogers argues that since Algeria profits from England's progress, the genius of the English race and Queen Victoria deserves to be celebrated. On the symbolic level, she wonders about the possibility of "the effigy of our beloved Queen" (39) in order to emphasize that Algeria would be better off as a British colony rather than a French one. This is her way of consolidating British imperial power. Again, Rogers assumes that if monuments are to be erected to commemorate the work of the colonizer in Algeria, it is more appropriate to direct them toward that of the English than that of the French. The Algerians insist on their "prefer[ence of] seeing one erected to Sir M. Peto" an Englishman "who had really provided the people with work, and benefited the town" (Rogers, 1865: 53). Said argues that colonial discourse consolidates imperial power through "ideological formations that include notions that certain territories and people require and beseech domination" (Said, 1994: 8). In her writing, Rogers maintains that Algeria "requires" the intervention of the English to improve its people's conditions. They, in turn, become the "white man's burden" for Britain.

Imperial activities generally concern political governance and administrative work, Christian/ civilizing missions and economic interests. In A Winter in Algeria, the British presence involves two areas of activity: the Evangelical and/ or civilizing mission and the economic activity. The English capitalist Sir Morton Peto represents the latter. In Algeria, he invests his capital to create economic opportunities and profit his nation. Rogers writes: "The terms upon which Sir Morton Peto has undertaken this national work are equally advantageous to himself, and to the Government" (Rogers, 1865: 28). Therefore, as one of the successful "English capitalists [he] is said to own half the town of Algiers" (28; emphasis added). This involves "the proprietary attitude" of Orientalism and the idea that "the geographical space of the Orient" is "penetrated, worked over, taken hold of" (Said, 1995: 211) as Sir M. Peto does in Algiers. The other area to which the English oriented their imperial experience is the Evangelical mission. In the text, this is represented by Rev. George Albert Rogers, Rev. W. Ginsbury and other missionaries who are in Algeria for the "spread of the Gospel" (Rogers, 1865: 175). The aim was not only religious but also philanthropic since the missionaries opened up schools and libraries for Algerians. Rogers celebrates English ingenuity which is imported to Algeria informally through these instructional structures.

This interest in Algeria as an improved colony if subjected to the English is "[d]erived from the British view of themselves as 'natural leaders' and ... [Orientals] as children" (Greenberger, 1969: 57). Rogers extends this British "paternalism" to Algeria. Thus, she goes beyond the limits of the British Empire, but she keeps loyal to its discursive sites and imperialist ideologies. Besides, she joins the British view that the French were weak and effeminate in their imperial affairs, a view that was cultivated by other British travelers to Algeria like Thomas Campbell. ${ }^{10}$ As a matter of fact, Algeria becomes a paradigmatic colony almost in the same way as British India was for the majority of colonial writers. 
To Rogers, too, Algeria could have been the North African British Raj. ${ }^{11}$ Throughout her text, she makes reference to India and draws many analogies between the two colonies. For instance, the 'natives' of both are important for preserving the hierarchical structure of empire. She writes: "All our movables were forthwith brought down, and placed thereupon by the sturdy Arabs, without whom Algeria could get on no better than could British India without the natives" (Rogers, 1865: 123). Since the "sturdy Arabs" are viewed as the servants of Mrs. and Mr. Rogers and compared to the Indians, it is obvious that she consolidates the hierarchy of colonizer and colonized. It is true that the Indian Mutiny of 1857-8 grew as a traumatic event for the Britons since it revealed to them the instability of their rule in India. This idea was by and large popularized in the literature of empire, and Rogers is no less different from other colonialist authors. Thus, in the preface to her travelogue, she compares the "widespread insurrection that broke out in Algeria" (viii) to the Indian Mutiny. She elaborates her analogy by claiming that "the threats of the Arabs, about 'driving the French into the sea,' are as likely of fulfilment, as those of the Sepoys regarding the English in India" (Rogers, 1865: 273-74). ${ }^{12}$ Obviously, Algeria provides Rogers a paradigmatic colony for her Anglo-centric imperial desire which is projected on India, the British Empire's "jewel in the crown."13

\section{Rogers's Feminist Stance}

Burton claims that Victorian women's "quest for inclusion in the imperial state" was "an extension of the call for representation in the nation" (Burton, 1994: 7). Because they did not have the right to suffrage, they enjoyed almost no representation in the English government just like colonized Algerians. Rogers emphasizes the deplorable state of Algerian women as they wait for "the representation of their plight and the redress of their condition" by "their sisters in the metropole" (7). Rogers's feminist discourse is expressed on a metaphorical level by emphasizing Oriental women's status as "subjects in need of salvation by their British feminist "sisters"" (1). This was a common belief among Victorian female travelers, but less prevalent in texts by males. Thus, as a Victorian woman writer she sets women, Victorian or Muslim, at the heart of her travelogue.

Dwelling on what she feels are the superior Christian values of British colonizers, Rogers highlights in her travelogue how Algerian women have been hampered in social hierarchy by their Muslim faith. They are barred from the public space and are confined to the harem or zenana. ${ }^{14}$ Their "existence outside [the domestic space] is considered an anomaly, a transgression" (Mernissi, 1978: 139) that obliges them to wear the veil. Rogers asserts that the veil "indeed applies to all Moslem women without exception" (Rogers, 1865: 84). Each time she meets 'native' women in the streets of Algiers or other towns, she is surprised by their veiling: "We saw several veiled figures eagerly crowding around this little aperture" (23). She continues: "one of the most singular sights here is that of the Moslem veiled women, who are to be seen in every direction. 
They never leave their homes without a sort of handkerchief across the face fastened below the eyes" (40). Mernissi states that the "veil means that the woman is present in the men's world, but invisible; she has no right to be in the street" (1978: 143). A cultural parallel can be drawn between the Oriental woman's "seclusion" (140) and the Victorian ideology of the "angel in the house." The separate spheres ideology kept many Victorian women inside the limits of private space. Thus, both groups of women will never enjoy the public liberty men have unless their cause is pleaded.

In Rogers's text, this analogy is explained by the fact that some British female travelers she meets in Algeria prefer to remain anonymous since they are apprehensive about assuming a public face even when away from home. Rogers notes: "We had the pleasure of making acquaintance this evening of Miss L. who had been Miss Crawford's companion in Algeria" (Rogers, 1865: 3). In other statements she persists in not identifying Miss L. while she names others. She writes: "Miss L. is a sort of rival to Miss Pardoe" (3). In the text, we repeatedly encounter such words as Mrs. -----" (67), "Mrs. C." (78), "Mrs. E." (238) and numerous similar expressions. Rogers explains that she deliberately chooses not to name some of the ladies she meets in Algeria because of the rules of patriarchy and male-defined negative stereotypes for entrepreneurial and venturesome women. She writes: "I have not heard of a single instance, as far as I remember, in which Englishmen have given the slightest countenance to speculative emigration, on the part of their fair countrywomen" (302; emphasis added). The implication is that English men do not encourage women to travel, for they still believe that they are the 'fair and weak sex' and are physically and morally incapable of bearing the difficulties of travel. Traveling means entering the public arena, and this runs counter to the private constructions of space defined by Victorian society for women.

The private sphere for Oriental women concerns their role as protectors of the harem or zenana. As such, they had no right to (or need for) education according to the rules of Muslim societies. Such obscurantism is gender-bound as Muslim women are not entitled to receive education. The male 'masters' do not allow their daughters or sisters to go to school, ${ }^{15}$ and school rules do not allow girls in. Rogers states that schools are only allowed for Muslim boys, "girls being of course deemed incapable of education" (Rogers, 1865: 298). She adds that the Algerian "officials saw no manner of good in educating Moorish women" (198). Thus, she paraphrases Tennyson's words ${ }^{16}$ in commenting that "they did not believe that "as the wife is so the husband is"" (198). To them, there is no equality between men and women. Edwards explains this idea by the fact that men "do not like their wives and daughters to be more learned than themselves" (1976: 17). Besides, due to domestic confinement, women have no right to receive education in the public space. Muslim women's bondage and the denial of their rights to education and social or economic freedom are linked to their veiling. Franz Fanon claims that the "woman seen in her white veil unifies the perception that one has of Algerian feminine society" (Fanon, 1965: 36). ${ }^{17}$ Missionaries like Rogers perceived the veil as the fabric with which Muslim women's socio-political repression was woven. 
An additional topic explored in Rogers's writing raises the political issue of indigenous women's rights in the traditional legal structures such as the Muslim tribunal. These are viewed as institutions which hinder women's rights and deny them public and political existence. She claims that "Moslem women are not allowed to enter the Mahakma, or tribunal. A little window, with iron gratins, is reserved for their use when they have a cause to plead" (Rogers, 1865: 22-23). They are not allowed to participate in the processing of such serious matters as justice and human rights. To their male 'masters', their words count for nothing, so they have to be unseen when they are entitled to take part in legal proceedings. Women's lack of political and legal enfranchisement in Algerian society contributes to their inferior family status. Rogers notes that the most glaring aspect of this lack enfranchisement lies in the fact that a Muslim man has the right to marry four wives and repudiate the marriage bond whenever he wants to without the consent of his wife or wives or due process of the law. Rogers dwells on an anecdotal Kabyle man whose connubial life is divided among four wives who make up his "acquisitions" (Rogers, 1865: 42). The word 'acquisition' denotes property which for Rogers is anathema; equivalent to the social structures of master-slave which, by this time, Britain had renounced. As for repudiation, she gives us another example which shows that polygamy followed in many cases by repudiation serves more the power of the husband than the 'wives.' Another anecdotal account focuses on "Hassan [who has] four wives" (105), and while he pays very careful attention to the last and youngest wife the first three are forced to experience their "repudiation" (106). Repudiation, exercised solely by male whim, is for nothing but domestic tyranny; yet another instance that abrogates the social and political rights of women.

Women have to undergo the domestic tyranny of men as they are always 'slaves' to their male 'masters'. Marriage makes 'wives' subservient to dominant husbands who act more as 'masters' than as husbands; women are slaves to their "future lords or masters" (84), states Rogers. Again, anecdotally speaking, she recounts an instance of a "savage husband [who] threw his wife on the ground, fastened her by ... cords to ... four stakes, and then, taking a long stick, began dealing heavy blow on the person of the unfortunate creature" (60). Before marriage, women, young or aged, are dominated by their fathers or brothers. Boys when grown up become the Oriental woman's "superiors and masters, if not tyrants. With them she may no longer eat, when their years permit them to share the father's meal" (59). Muslim women undergo a double exclusion from power. Being barred from the public sphere, they are "deprived of power even within the world in which they are confined, since it is the man who wields authority within the family" (Mernissi, 1978: 139).

Rogers contends that as Algerian women were unfortunate under male domination, their condition beseeched the salvation of British women in the framework of the feminist branch of Christian missions. She laments with sympathy: "Oh, Christianity, haste to tear the fetters, and rend the veil from these degraded ones: no meaner power can save them" (Rogers, 1865: 59). Actions of salvation are not scarce in Algiers. For instance, to introduce Muslim women to education and enlightenment, a library is 
opened up in Algiers by English women who "had kindly undertaken the offices of librarians" (145). In Algeria, British feminists contributed to the evangelical mission by working for the enlightenment of Muslim women. As a feminist traveler and a missionary's wife, Rogers emphasizes the missionary work focused on the enlightenment of Algerian women facilitated by British (and French) ladies. Providing for the education of Algerian women relies on inculcating civil notions like equality between the sexes in order to defend against the violence of patriarchal rules.

Rogers felt that further missionary work warranted the attention of Victorian ladies because the improvement of the condition of their Algerian 'sisters' was still imperative. The author calls upon British women to "try to adopt Miss Whately's plan, and get the New Testament thus read to them," which would introduce them to religious enlightenment (29). In addition to British religious instruction, Rogers notes that French ladies have also established schools for them. She emphasizes that she will not leave Algiers without paying a "visit of inspection and encouragement to Mme Luce's school" (199) for women. The words 'inspection' and 'encouragement' imply that Rogers has some influence and authority as a Victorian feminist and a missionary. 'To inspect' generally implies 'supervision', and 'to encourage' means moral 'support'. These words underscore her prerogative as a feminist and a missionary woman whose voice often took precedent over other committed English (and French) feminists and missionaries in Algeria.

Emancipation of Algerian women would lead to opening up a dialogue about women's empowerment in Victorian society. Along with the "separate spheres ideology," the ideology of the "fair sex" attributed to Victorian women the features of "emotion, passivity, submission, dependence, and selflessness" (Kent, 1999: 179) while upholding the idea of their natural subordination to men. Working-class women, caught in the throes of the industrial revolution in England, were doubly hindered by Victorian social constructions. They endured domestic dominance by their husbands and exploitation by factory owners. It is true that to every rule there are exceptions, so there were also many Victorian women who enjoyed liberty and independence and felt urged by the necessity of saving their sisters. They started by fostering debate over "the legal subordination of one sex to the other" (Mill, 1998: 520). However, this was not restricted to feminists. They were joined by male intellectuals like J. S. Mill who argued against gender inequality and John Ruskin who defended it. ${ }^{18}$

Oriental women's subordination to men becomes a metaphor through which the feminist struggle in Britain expresses itself. In Rogers's texts, the desire to emancipate Algerian women from the limits of gender roles construed by socio-religious rules fuels even more the female Victorian traveler's desire to improve the condition of all Victorian women. ${ }^{19}$ Algerian women serve the Victorian traveler as "a mirror of their desire" (Jenkins, 2004: 16) to improve the status of women in their society. The push for education for Algerian women is mirrored in Victorian women's call for more socio-political and economic rights. Challenging men's power over women in the Algerian context is echoed in Victorian women's questioning of their inferior status as household protectors, impeded from enjoying rights to suffrage like men. According to 
Burton, the majority of Victorian travelers were suffragists, who worked for the promotion of the right for "women's suffrage" (Burton, 1994: 3), so defending Oriental women's political rights reflects their commitment to women's political enfranchisement at home.

A further parallel to note with respect to similar gendered issues between Victorian and Algerian women is related to class. Rogers contends that gender roles are classbound in Muslim societies. She writes:

Amongst the richer Moslems the degradation of the women is mental and moral. Superadded to this, amongst the poor classes the husband lays upon the shoulders of his wife, every conceivable burden. As far as possible, he lives the most perfect idleness, as one of the lords of creation. To the lot of the Arab woman it falls, to till the ground, to reap the harvest, to grind the corn, to knead the bread. (Rogers, 1865: 58-59)

Similarly, Victorianist scholars also believe that gender roles were class-bound in Victorian society. For instance, Josephine M. Guy (1998: 466-67) argues that there was a substantial difference between the condition of working-class women and those of the middle class. Working-class women were almost slaves to their husbands and factory owners (yet, ironically they were opening in public space), whereas middle-class women were confined to the home and they did not enjoy equal status with men.

In addition to drawing parallels between Algerian and Victorian women, Rogers focuses on the independence of women travelers as entrepreneurs to question the metaphor of the "angel in the house" and the ensuing stereotype it engendered for women as "the weaker sex." Mills claims that traveling to distant countries allowed women to demonstrate that they were "strong, exceptional [and] somehow managed to escape the structure of patriarchy" (1991: 29). Rogers argues for this point by drawing on her personal experiences as a traveler and those of other Victorian women she meets in Algiers. Her observations and actions in Algiers show that she is a strong and independent woman who breaks down the barriers of the household in order to venture into the unknown. Her independence stems from the cultural position she acquired as author and her class status as wife of Rev. Rogers. In Algeria, her main travel companion is her husband, but she tells us that on several occasions she moves from one place to another all alone or with other Victorian ladies, and she does so as a "pedestrian" (Rogers, 1865: 107). This shows that she is physically disposed to bear the difficulties of travel. To reinforce this idea, she claims that her husband has more difficulties than she. When they have experienced fever, she manages to "subdue it" while her husband "has been less fortunate. He has been, and is still suffering in various ways" (54). Her travels and those of other women like Miss L., an "enterprising traveler" and "a sort of rival to Miss Pardoe" (3; Italics added), show that women are entrepreneurial and independent. This departs from their male-defined roles as weak and incapable of physically enduring the difficulties of activities like travel.

"Travel broadens the mind" the saying goes. So do Rogers's travels in Algeria which allow her to open herself to new horizons and widen her knowledge of the world. In her travelogue, she casts herself as a learned authority on Algeria by sharing her 
experiences with future female visitors. The knowledge she transmits to the reader falls into different categories that are geographical, ethnological, botanical and zoological. For instance, it is her expertise on the Algerian climate that makes her integrate into her text a list of recommendations for English travelers. She writes:

Three special hints I must here commit to paper, for the benefit of those who may visit Algiers: --

1. Be well provided with warm clothing, and wraps.

2. Take rooms facing the south. Hot though the climate be, eschew a northern aspect for the winter.

3. Never remain out at this season between the hours of three and five, when the temperature gets suddenly, and sensibly chilly. The doctors are very particular in enforcing this injunction.* [emphasis added] (53)

The asterisk reads "For further particulars relating to the climate, see Appendix" (53), and it shows that Rogers has expert geographical knowledge about Algiers which she aspires to share with other travelers. The separate spheres ideology offers a few opportunities to women to participate in the public sphere of knowledge. However, Rogers's expert knowledge which she puts in circulation after the publication of her travelogue challenges this ideology.

\section{Conclusion}

In conclusion, Rogers's travelogue obviously combines Orientalist and Feminist discourses in order to cross discursive boundaries and to subvert gender roles. Most Victorian women travelers wrote about British colonies, but she writes about French Algeria. However, she refers to British imperial prestige and Queen Victoria's glory as empress so as to project Britain's imperial desire on Algeria. As a woman traveler challenging patriarchy, she focuses on the need for liberating Algerian women which will, in turn, liberate Victorian women from gender restrictions. Some male writers allude to the condition of Oriental women only to consolidate superior English identity. They celebrate British imperial heroes who are "determined that they themselves should act as the protectors of ... [Oriental] women" (Metcalf, 1994: 94) to legitimate empire. She like other female travelers wants to affirm her heroism as a woman challenging patriarchal rules and working for subverting gender roles.

This feminist-Orientalist attitude finds intertexts in contemporary writings about neo-colonialism and patriarchy or misogyny. Parallel to recent Western military intervention in Afghanistan, many feminists and humanitarians went there to help Afghan women in their struggle against the misogynist violence of the Taliban regime. Arguably, Sally Armstrong's Afghan-set works like Veiled Threat: the Hidden Power of the Women of Afghanistan (2003) epitomize this feminist commitment to the cause of Afghan women. This shows that feminist struggle is not 'time-or-place-specific;' 
whatever the time or place, the terminologies change but the objectives remain the same as long as misogyny and patriarchy prevail.

\section{Notes}

1. In the beginning of the second half of the nineteenth century, Victorian travelers started to be widely interested in India and other colonies and produced a discourse that had Orientalist and feminist undertones. Mary Carpenter's Six Months in India (1866) and Emily Eden's Up Country: Letters Written to Her Sister from the Upper Provinces of India (1867) held such views about India. These travelers were preceded by female authors like Emily Brontë and her sister in their allusions to colonial India in Wuthering Heights (1847) and Jane Eyre (1847). This colonial interest induced writers like Ellen M. Rogers and others to write about Algeria, and in painting Barbara Bodichon produced most of her tableaux on Algeria in the period between 1850 and 1870 .

2. From 1830 to 1962 , Algeria was a French colony, and it assumed the same pivotal role as Anglo-India did for the second British Empire. Both colonies provided the frame of reference in terms of the ideologies of Orientalism when other French or British colonies were approached. French Algeria, then, offers a metaphor for Anglo-India, and the fact that Rogers makes enough references to the latter substantiates this idea.

3. In Culture and Imperialism (1993: 81-82), Edward Said uses this concept to refer to the works of art that were produced within the culture of imperialism. Photography, painting, opera, and literary works constitute important examples of these cultural forms.

4. Seddiki has chosen Mrs. Ellen G. Rogers as the name of the author, but it must be Mrs. G. Albert Rogers as it is inside the original book. This borrows from her husband's name George Albert Rogers. I choose, however, Ellen M. Rogers for the feminist bearing of her text, and it sounds more appropriate to the essay's main argument. When the text was first digitalized by Google, her name was changed for Ellen M. Rogers. In August 2012, it was published another time by Ulan Press, and this name was kept.

5. Among other ideas, British feminist authors in the Victorian period advocated women's substantial participation in the public sphere of power and knowledge. Thus, they called for more education opportunities for women and their right to vote.

6. This is rooted in Puritanical Christian teaching which was used, in the British colonies, to spread brotherly love among the colonized and to induce them to love the colonizer. In Algeria, Catholic or Papist teachings were rather used to dissipate Muslim religion as a component of Algerian identity. In her text, Rogers emphasizes this distinction by constantly referring to Christian England and Catholic France.

7. In Discipline and Punish: the Birth of the Prison (1979), Michel Foucault argues that modern society functions like a prison, and the state disciplines its subjects without punishing them. Similarly, the 'natives' have to be disciplined by the imperial state, and the Christian mission is one apparatus for disciplining them by teaching them the values of respect and love.

8. Progress was one of the principal attributes of Victorian society. The Industrial Revolution brought about technological changes which, in turn, created a revolution in ideas. The Victorians believed in their mission to take this progress to societies which did not profit from its blessings. This is why empire blossomed during this period. In Heart of Darkness (1902: 36), Joseph Conrad uses the expression "pioneers of progress" to name the Victorian men (and women) who ventured to the colonial world to take progress and its blessings. 
9. In Heart of Darkness, Conrad uses this expression to celebrate the work achieved in the name of progress by the English in Africa in contrast with the failure of other European powers to take civilization and progress to the colonized (1902: 36). For instance, he suggests that the French are rather detrimental to the colonized Africans (1902: 40).

10. Osman Bencherif argues that Thomas Campbell was "one of the first English travellers to visit Algeria after the French occupation" (1997: 105). In his writings, he expresses "a complacent sense of national [English] superiority as he counts up the blessings of his native country" (1997: 105).

11. British Raj is the name given to India soon after it turned a formal British colony following the Indian Mutiny of 1857-8 and Britain's success to contain the Sepoy rebellion.

12. In Haiti, the French were literally thrown 'into the sea' after Toussaint L'Ouverture's rebellion, followed by Jeans Jacques Dessalines, who declared Haitian independence in 1804. Arguably, this was weighing on the minds of the French in Algeria. Likewise, the Indian Mutiny was traumatizing the English whenever the colonized rebelled.

13. It is Paul Scott who uses this expression for the first time in his The Raj Quartet, Volume 1: The Jewel in the Crown (1966).

14. Harem or zenana refers to the specific place in the Oriental house where women are confined in order to keep them out of men's sight. In feminist studies, they are used as generic terms for Oriental women's bondage and their confinement in the domestic sphere.

15. The Muslim schools of the time were religious. They are called zaouïa, and they intend(ed) to teach Muslim boys how to read and write through the Quran.

16. In "Locksley Hall" (1835), Lord Alfred Tennyson writes the following lines: "As the husband is, the wife is: thou art mated with a clown, / And the grossness of his nature will have weight to drag thee down."

17. In "Algeria Unveiled," the first chapter of A Dying Colonialism, Frantz Fanon deals with how socio-political the veil is in defining the extent to which the Algerian woman has or has not power.

18. In Sesame and Lilies, John Ruskin adheres to the separate spheres ideology. To him, "man's power is active, progressive, defensive" and woman's power is "rule" (1998: 506) of the house. However, John Stuart Mill opposes this idea and states that "the principle which regulates existing social relations between the two sexes ... is wrong in itself" (1998: 520).

19. Josephine M. Guy claims that "Victorian debates about sex and gender were classbased" (1998: 466). Working class women were less concerned with their degraded condition because they were submerged by their duties as factory workers, wives, mothers or daughters. The only women to have risen against it were from the middle class (1998: 467).

\section{References}

Bencherif, Osman (1997): The Image of Algeria in Anglo-American Writings, 1785-1962. Lanham: University Press of America.

Bhabha, Homi K. (2004): The Location of Culture. London: Routledge.

Burton, Antoinnette (1994): Burdens of History: British Feminists, Indian Women, and Imperial Culture, 1865-1915. North Carolina: The University of North Carolina Press.

Cherry, Deborah (2002): "Earth into World, Land into Landscape: the Worldling of Algeria in Nineteenth-Century British Feminism." In Jill Beaulieu and Mary Roberts, eds. 
Orientalism's Interlocutors: Painting, Architecture, Photograph. Durham: Duke University Press, 103-130.

Conrad, Joseph (1983): Heart of Darkness. Harmondsworth: Penguin Classics.

Edwards, Mathilda Betham (1867): A Winter with the Swallows. London: Hurst and Blackett Publishers.

Fanon, Frantz (1965): A Dying Colonialism. Trans. Haakon Chevalier. New York: Grove Press, Inc.

Greenberger, Allen J. (1969): The British Image of India: a Study in the Literature of Imperialism 1880 -1960. London: Oxford University Press.

Guy, Josephine M. (ed.) (1998): The Victorian Age: an Anthology of Sources and Documents. London: Routledge.

Jenkins, Ruth Y. (2004): "The Gaze of the Victorian Woman Traveler: Spectacles and Phenomena". In Kristi Siegel, ed., Gender, Genre and Identity in Women's Travel Writing. New York: Peter Lang, 15-30.

Kent, Susan Kingsley. Gender and Power in Britain, 1640-1990. London: Routledge, 1999.

Mernissi, Fatima (1978): Beyond the Veil: Male-Female Dynamics in Modern Muslim Society. Bloomington: Indiana University Press.

Metcalf, Thomas R. (1994): Ideologies of the Raj. Cambridge: Cambridge University Press.

Mill, John Stuart (1867): Considerations on Representative Government. New York: Harper \& Brothers, Publishers.

Mill, John Stuart (1998): "From the Subjection of Women." In Josephine M. Guy, ed., The Victorian Age: an Anthology of Sources and Documents. London: Routledge, 520-34.

Mills, Sara (1991): Discourses of Difference: an Analysis of Women's Travel Writings and Colonialism. New York: Routledge.

Parry, Benita (1972): Delusions and Discovery: Studies on India in the British Imagination 1880-1930. Los Angeles: University of California Press.

Rogers, Ellen M. (1865): A Winter in Algeria: 1863-4. London: Sampson Low, Son and Marston.

Ruskin, John (1998): "From Sesame and Lilies". In. Josephine M. Guy, ed. The Victorian Age: an Anthology of Sources and Documents. London: Routledge, 505-519.

Said, Edward W. (1995): Orientalism: Western Conceptions of the Orient. Harmondsworth: Penguin Books.

Said, Edward W. (1994): Culture and Imperialism. London: Vintage.

Seddiki, Sadia (2010): "Mrs Ellen G. Rogers's A Winter in Algeria and the Perpetuation of Colonial Discourse”. Campus, 18: 30-39. 